\title{
Morphological Responses Explain Tolerance of the Bamboo Yushania microphylla to Grazing
}

\author{
Kesang Wangchuk, ${ }^{1}$ Andras Darabant, ${ }^{2}$ and Prem Bahadur Rai ${ }^{1}$ \\ ${ }^{1}$ Renewable Natural Resources Research and Development Center, Ministry of Agriculture, Bumthang, Bhutan \\ ${ }^{2}$ Department of Forest and Soil Sciences, Institute of Forest Ecology, BOKU University, Vienna, Austria
}

Correspondence should be addressed to Kesang Wangchuk; kesangwangchuk@rocketmail.com

Received 5 June 2014; Accepted 9 August 2014; Published 19 August 2014

Academic Editor: William K. Smith

Copyright ( 2014 Kesang Wangchuk et al. This is an open access article distributed under the Creative Commons Attribution License, which permits unrestricted use, distribution, and reproduction in any medium, provided the original work is properly cited.

\begin{abstract}
Mechanisms of tolerance of the bamboo Y. microphylla to ungulate herbivory were investigated by measuring above- and belowground morphogenetic traits and biomass allocation patterns of the bamboo Y. microphylla under grazed and ungrazed conditions in a Himalayan mixed conifer forest. Data were collected from 5 populations consisting of 10 ramets each in adjacent grazed and ungrazed plots. Compared with ungrazed ramets, the aboveground morphological modifications of grazed ramets were higher culm density, shorter and thinner culms, shorter internode, and shorter top leaf. The belowground morphological modifications for the grazed ramets were thinner rhizomes, lower rhizome biomass and dry matter, more nodes, and shorter internodes. Despite the lower biomass and dry matter, the root-to-shoot ratio was higher for grazed ramets. Results suggest that Y. microphylla subjected to herbivory shows aboveground overcompensation in terms of densification at the cost of belowground biomass, but at the same time maintains a higher proportion of belowground reserves, as compared to ungrazed conditions. These responses provide adequate evidence to conclude that Y. microphylla tolerates ungulate herbivory through above- and belowground morphological modifications.
\end{abstract}

\section{Introduction}

Plant responses to herbivory are well studied [1-3]. They include a series of mechanisms to cope with the effects of defoliation, including chemical and structural changes in plants [4]; adjustments of plant morphology, such as increased branching and tillering, resulting from the loss of apical dominance; the reallocation of below-ground carbon stores into new aboveground photosynthetic tissue; and increased photosynthesis and growth rates [5]. The ability of plants to grow and reproduce after defoliation is termed as tolerance and the degree of this tolerance is referred to as compensation [5]. Defoliation may trigger excessive growth and reproduction, called overcompensation, or lead to incomplete replacement of missing tissues, called undercompensation [6]. Plant fitness may determine compensation response to herbivory, in that increasing competition and decreasing nutrient availability do not lead to compensation, which occurs only with abundant nutrient supply and lack of competition. Given possible differences in compensatory patterns between different biomass compartments, Trlica and Rittenhouse [7] proposed a holistic investigation of compensation mechanisms focusing on grasses, where fitness depends on longevity, asexual reproduction, and biomass production. Clonal architecture may enable plants to effectively respond to environmental constraints however, modifications in plant morphology as a mechanism of tolerance against herbivory have been comparatively little studied in case of clonal plants [6].

Clonal integration has been identified as an important mechanism of tolerance against herbivory, primarily through the reallocation of assimilates between ramets experiencing different intensities of defoliation $[8,9]$. Clonal plants are also of special interest for forest dynamics, as their herbivory can frequently lead to the formation of recalcitrant understory layers [10] through clonal integration [9]. These understory layers can serve as ecological filters to tree regeneration [11] and potentially alter successional pathways 
[12]. Clonal plants with rhizomatous and caespitose growth forms show different degrees of tolerance and compensatory growth mechanisms to herbivory. Rhizomatous growth form has a higher herbivory tolerance, as rhizomes function as important belowground storage organs for both carbon and nitrogen [13]. Some compensation mechanisms to tolerate herbivory include rapid growth rates and more horizontal display of leaf blades $[14,15]$. The tiller size-density compensation mechanism leads to high tiller population densities with small tillers [16]. Yan et al. [17] reported that grazing reduced root biomass but increased the total root-to-shoot ratio in alpine grassland, further indicating an important mechanism in plants to tolerate herbivory. Increased gas exchange rates in tissue, increased resource allocation to shoots, and increased nutrient absorption following defoliation are important physiological functions that can increase the plant's capacity to compensate or tolerate herbivory and thus increase resilience to herbivory [14, 15].

Bamboos are clonal, rhizomatous grasses and frequently dominate forest understories in temperate and tropical climates. Forage from forests frequently represents the most important source of animal forage and is essential in maintaining agricultural production as a basis for local livelihoods in many parts of the world [18]. Bamboos are important forage resources not only for domestic herds, but for wildlife, such as panda [19] and deer [20]. However, the tolerance of bamboos to herbivory has been little studied. Yokoyama and Shibata [21] provided the only evidence on morphological response of Sasa nipponica to herbivory, which included miniaturization and densification of culms, thinner culms, shorter top leaf, and lower aboveground biomass. Darabant et al. [22] also noted shorter genet of grazed Yushania microphylla when compared to ungrazed plot. However, these studies emphasize only aboveground responses and are deficient in belowground responses to herbivory. Amongst the dwarf bamboo species, Sasa nipponica is the only species adequately explored for morphological adaptation to herbivory and little is known of Y. microphylla, which is also an important forage for native cattle in the eastern Himalaya. Further, S. nipponica differs from Y. microphylla in growth habit. While the former is a monopodial bamboo with leptomorph rhizome, the latter is a sympodial bamboo with pachymorph rhizome. The aboveground morphological responses can only be understood in the context of simultaneous belowground responses, which is the focus of the present study. In the experiment reported here, we measured selected above- and belowground morphological traits of Y. microphylla in grazed and ungrazed plots in the mixed conifer forests of central Bhutan. Our main objective was to investigate the tolerance of Y. microphylla to ungulate herbivory, expressed through morphological adaptations and biomass allocation.

\section{Materials and Methods}

2.1. Study Sites. We selected a mixed conifer forest above Hurchi in Chumey Valley, located in Bumthang district of central Bhutan, as the area that well represents mixed conifer forests with $Y$. microphylla understory, grazed by sedentary and migratory ungulate and yaks. The research plots lie on a gentle, east facing slope at a mean altitude of $3225 \mathrm{~m}$. The area is dominated by metasediments and gneisses of the main crystalline belt of the high Himalaya [23]. The annual precipitation is $1300-1500 \mathrm{~mm}$, most of which falls between May and early October [24]. The mean maximum temperature of $+14.6^{\circ} \mathrm{C}$ is recorded in July and the mean minimum temperature of $-8.3^{\circ} \mathrm{C}$ is recorded in January [25]. Over 80 percent of the understory cover is dominated by Yushania microphylla, which is homogenously grazed to an average maximum height of $1.2 \mathrm{~m}$.

2.2. Species under Study. Y. microphylla is a sympodial bamboo with pachymorph rhizomes [26], which are extremely hardy and grow $20 \mathrm{~cm}$ deep into the soil [27]. The rhizome necks are hollow and the internodes are smooth and blackened with a waxy ring below the nodes [28]. The species bears tufts of short leaves about every $15 \mathrm{~cm}$ and if left ungrazed, culms grow erect up to $3.2 \mathrm{~m}$ height $[26,29]$. Therefore, the species is not a dwarf bamboo. Yushania microphylla is a frequently dominant understory species in temperate and subalpine regions in Bhutan between 2300 and $3500 \mathrm{~m} \mathrm{[28].} \mathrm{In} \mathrm{subalpine} \mathrm{regions,} \mathrm{the} \mathrm{species} \mathrm{is} \mathrm{an}$ important source of yak forage in winter [30], whereas in temperate forests it is frequently grazed by migratory and sedentary domestic ungulates during summer. In particular, large forest gaps, mostly created through logging, frequently become dominated by $Y$. microphylla and serve as main feeding grounds for domestic herds. Y. microphylla is also one of the main sources of forage and habitat for the endangered red panda (Ailurus fulgens) [25].

2.3. Sampling Design and Treatments. Experimental plots were established in 1996 and consisted of five pairs of $6 \mathrm{~m} \times$ $4 \mathrm{~m}$ fenced exclosures and adjacent grazed areas located in the centres of small forest openings dominated by Y. microphylla. Exclosures were designed to keep out large herbivores but allowed access of small herbivores. A buffer of at least $1 \mathrm{~m}$ width was maintained and a $2 \mathrm{~m} \times 2 \mathrm{~m}$ plot was established within each exclosure and adjacent grazed area. By the time of field assessment, fenced plots had been excluded from herbivory for over 15 years. The majority of the rural households residing near the study site acknowledged the existence of high ungulate pressure with over 3 livestock units grazing on one hectare of forest [31]. This has been attributed to all categories of domestic animals and wildlife feeding on forage resources in the forest.

2.4. Measurement of Morphological Traits and Biomass. Measurements were carried out in the month of July 2012 before the plants of Y. microphylla started to flower in the same year. At the time of measurement, the plants were intact and alive and flowering did not affect the data collected. Ten ramets were randomly selected and sampled from grazed and ungrazed recording plots. Each plot was considered as a genet. Thus, in total 50 ramets each from grazed and ungrazed plots were used for measuring morphological traits. For aboveground biomass and morphology, we measured the total fresh and dry weight of shoots, culm height, length, 


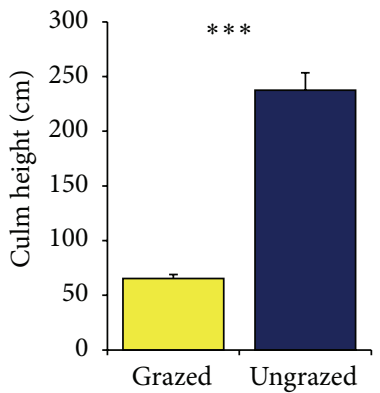

(a)

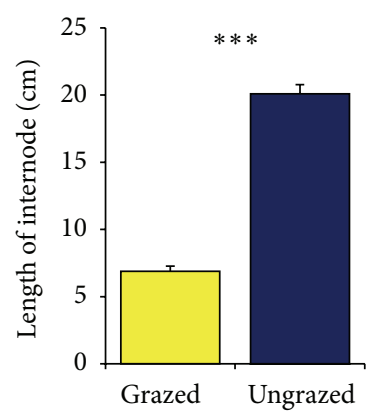

(e)

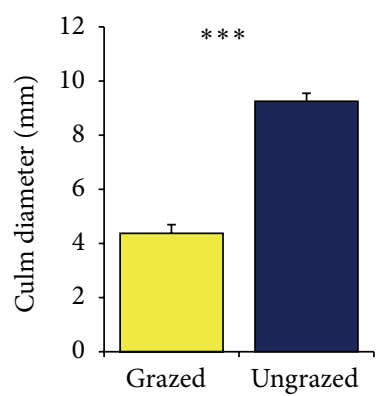

(b)

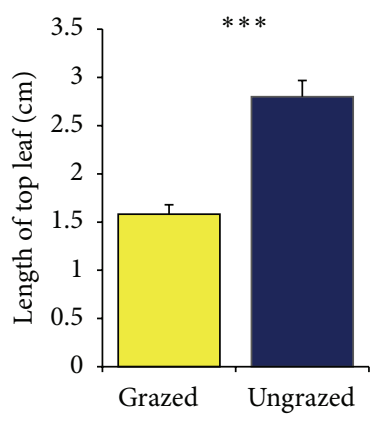

(f)

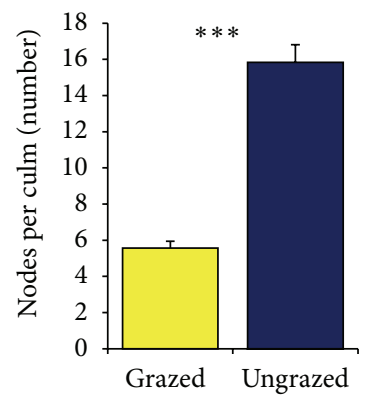

(c)

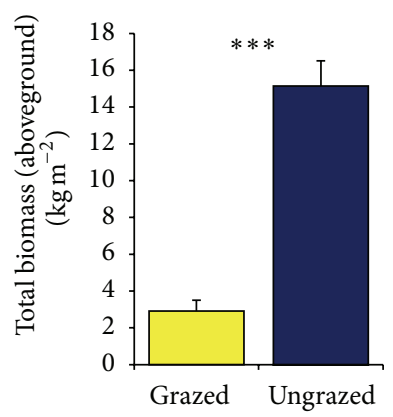

(g)

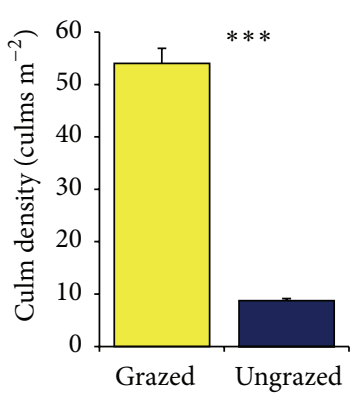

(d)

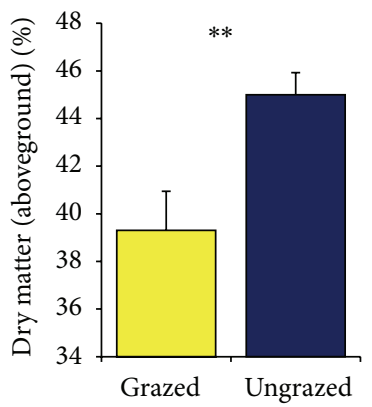

(h)

FIGURE 1: Aboveground morphological differences between grazed and ungrazed bamboo. Error bars represent the standard error of means. ${ }^{* *} P \leq 0.01,{ }^{* * *} P \leq 0.001$.

and diameter of the first internode aboveground level, top leaf length, and the total number of nodes per culm. In addition, culm density was recorded from an area of $1 \mathrm{~m} \times$ $1 \mathrm{~m}$. For belowground morphology, we measured the rhizome diameter at $5 \mathrm{~cm}$ distance from the culm. The number of nodes within $15 \mathrm{~cm}$ length of rhizome and length of the first internode were also measured from the culm. An area of $1 \mathrm{~m}$ $\times 1 \mathrm{~m}$ was dug to a depth of $40 \mathrm{~cm}$ and the soil block along with intact roots of ramets was taken out. The roots were separated and cleaned and the root biomass was weighed. It was followed by collection of subsamples for estimation of root dry matter. Subsamples of both leaves and roots were processed and oven dried at $60^{\circ} \mathrm{C}$ for 48 hours after which dry matter weight was recorded. The dry weights of roots and shoots were used to calculate the dry matter percentage and root-to-shoot ratio.

2.5. Data Analyses. The dataset was tested for normalcy and homogeneity of variances using Shapiro-Wilk and Levene's tests, respectively. Wherever required, data was logarithmically transformed to meet the assumptions of ANOVA. Individual ramet measurements were used as replicates for both grazed and ungrazed treatments. Differences in the means of morphological traits and biomass between grazed and ungrazed treatments were assessed with paired-samples $t$ tests. Differences between means were considered significant if $P$ values were lower than 0.05 . The entire dataset was analysed with SPSS 21 [32].

\section{Results}

3.1. Effects of Herbivory on Aboveground Morphology. Morphological traits differed significantly between grazed and ungrazed bamboo culms (Figure 1). Grazed culms had significantly lower height (Figure 1(a)), diameter (Figure 1(b)), number of nodes per culm (Figure 1(c)), shorter internodes (Figure 1(e)) and top leaves (Figure 1(f)), lower aboveground total biomass (Figure $1(\mathrm{~g})$ ), and dry matter content (Figure 1(h)). On the contrary, culm density in grazed bamboo plots was more than five times greater than in the ungrazed plots and this difference was highly significant (Figure 1(d)).

\subsection{Effects of Herbivory on Belowground Morphology. Except} for the root dry matter (Figure 2(e)), the belowground morphological traits differed significantly between grazed and ungrazed bamboo plots (Figure 2). The measured values for rhizome diameter and internode length were significantly lower for the grazed plot (Figures 2(a) and 2(c)). However, the number of rhizome nodes within $15 \mathrm{~cm}$ from the culm base was significantly higher for the grazed plot (Figure 2(b)). The rhizome biomass per square meter in the grazed plot was significantly lower by a factor of two and half, as compared to the ungrazed plot (Figure 2(d)). However, on the basis of dry matter percentage, there was no significant difference between grazed (34\%) and ungrazed (35.5\%) plots (Figure 2(e)). Despite the lower biomass, the root-to-shoot ratio in grazed plots was about two times higher than the ratio in ungrazed plot (Figure 2(f)).

\section{Discussion}

The results of this study demonstrate the morphological modification of Y. microphylla as a result of 16 years of exclusion from ungulate herbivory. The responses of Y. microphylla to 


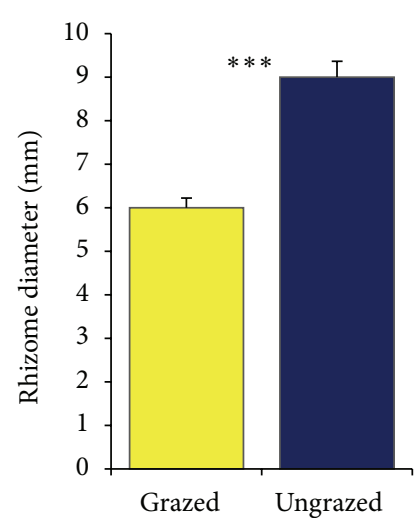

(a)

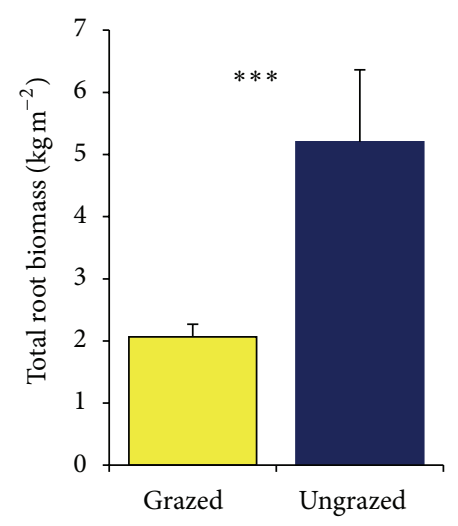

(d)

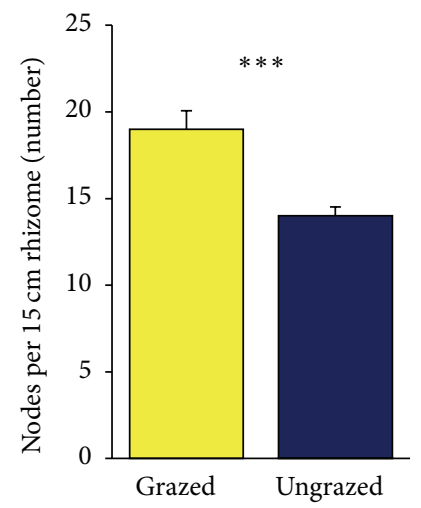

(b)

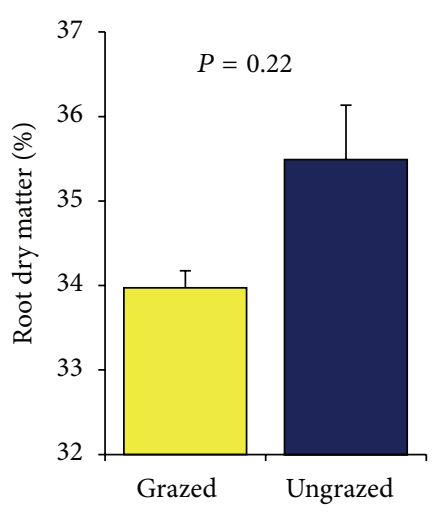

(e)

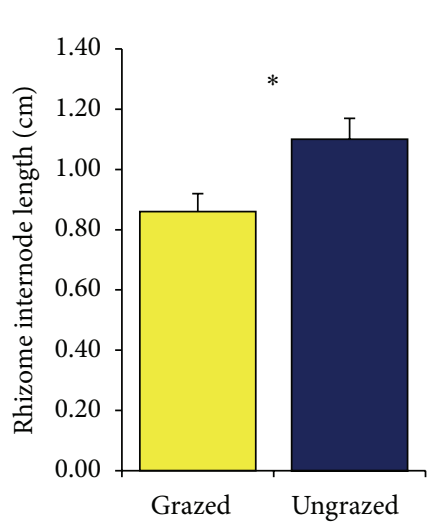

(c)

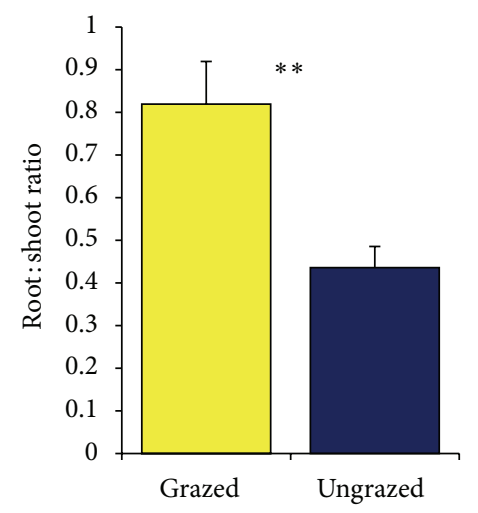

(f)

FIGURE 2: Belowground morphological differences between grazed and ungrazed bamboo. Error bars represent the standard error of means. ${ }^{*} P \leq 0.05,{ }^{* *} P \leq 0.01,{ }^{* * *} P \leq 0.001$.

ungulate herbivory were similar to those reported for Sasa nipponica, a dwarf bamboo grazed by sika deer [21].

Although this species has a pachymorph rhizome, intrinsically leading to dense culm growth even in the absence of herbivory, the greater culm density under grazed conditions suggests that herbivory has contributed to densification. Higher density of culms reflects plants' strategy to tolerate herbivory through rapid replacement of photosynthetically active tissues [7]. Increased branching and tillering are tolerance mechanisms of plants to herbivory and result from the lack of apical dominance and increased solar radiation [5]. Increased recruitment of new shoots as a response to removal of culms through harvesting has been reported for bamboo species $[33,34]$ and can be explained by the compensatory growth mechanism of plants responding to repeated defoliation [35]. Densification of culms as a response to herbivory was found to be a very quick process. In just over a year, Yokoyama and Shibata [21] found a threefold increase in the culm density of $S$. nipponica grazed by sika deer, compared to ungrazed conditions. Herbivore-tolerant plants are generally known to possess a large number of small tillers, as compared to herbivore-intolerant plants, which have a small number of large tillers [36,37]. Therefore, denser grazed plots with thinner culms appear be an important morphological response, indicating tolerance of $Y$. microphylla against herbivory. Densification has been reported to stimulate formation of basal meristems that impart higher resistance to trampling [38]. Besides herbivory, a few studies on sympodial bamboo $[39,40]$ also demonstrated the loss of biomass and consequent proliferation of small culms due to shoot harvesting and fire. Similar proliferation of culms following harvest was also reported by Vázquez-López et al. [41]. Decline in culm and ramet biomass with herbivory has also been reported for the bamboo Fargesia robusta [42].

Other important morphological adaptions of Y. microphylla to herbivory were shorter culms, leaves, and internodes. These observations were supported by reduced leaf weights found on grasses subjected to defoliation [43]. Yokoyama and Shibata [21] explained the presence of shorter leaves with thin and short culms as a mechanism to reduce defoliation severity by minimizing the loss of biomass due to herbivory [44]. These observations highlight the importance of defoliation-avoidance mechanisms in the resistance of $Y$. microphylla to herbivory.

Y. microphylla also displayed herbivore-induced morphological modifications belowground. The morphogenetic changes suggest that defoliation can have substantial impact on root and rhizome development [45], in spite of the fact that the maintenance of reserves in rhizomes is an important strategy to tolerate herbivory [44]. Rhizomatous grass species 
displayed shorter and fewer rhizomes when clipped aboveground and showed changes in biomass allocation patterns in favour of aboveground biomass [46].

Herbivory decreased the total root biomass, similar to the findings of Yan et al. [17]. Low dry matter of roots has been attributed to depletion of root carbohydrate reserves under frequent defoliation [47]. Our findings on reduced biomass correspond to the results reported on the rhizome response to frequent defoliation of Grassland Maku (Lotus pedunculatus) [48], Caucasian clover (Trifolium ambiguum) [49], and mixed-grass prairie [50]. In particular, when plants are wounded and stressed by external factors, metabolic imbalances occur, leading to a shift in dry matter partitioning from rhizomes to tillers [51]. Stout and Brooke [52] also reported that defoliation caused decrease in the supply of carbohydrates to the rhizomes and roots of pinegrass. Similarly, in our study, herbivory has stimulated culm densification, whereby carbohydrate reserves in rhizomes were probably used for producing a greater number of culms, explaining the reduced rhizome biomass and greater culm density in grazed plot. A decrease of carbohydrate concentration in the rhizomes with development of new shoots has been reported for the bamboo Phyllostachys pubescens [53]. Mechanisms of overcompensation aboveground may happen as a result of assimilate reallocation at the cost of belowground biomass and the activation of dormant buds $[7,36]$. Thus, our results on higher population densities and lower root biomass of grazed bamboo stands strongly indicate that aboveground overcompensation occurs at the cost of belowground biomass when the plants of Y. microphylla are subjected to long-term herbivory. The striking observation was on the number of rhizome nodes, which was higher in the grazed plot. This is in contrast to the aboveground morphology where the number of nodes was higher for ungrazed plots. Since culms arise from nodes, the greater number of nodes on rhizomes most likely explains the greater culm density in grazed plots.

Herbivory may have reduced the total root biomass of bamboo plants but has increased the root-to-shoot ratio, similar to the findings of studies on alpine grassland $[17,54]$. The greater root-to-shoot ratio of grazed plot suggests high tolerance of species to herbivory and may have favoured the species to adapt to frequent herbivory. This is mainly because greater root-to-shoot ratio is associated with increased plant capacity to capture more nutrients [55]. A high root-to-shoot ratio indicates larger reserves belowground, which increases plant tolerance to herbivory [3]. In this study, while both above- and belowground biomass increased over 16 years, the increase aboveground was stronger with grazing exclusion, indicating lower priority of resource allocation to reserves belowground in the absence of large ungulate herbivory. This further demonstrates that aboveground compensation occurs at the cost of belowground biomass reserves.

\section{Conclusions}

Ramets of $Y$. microphylla exposed to frequent herbivory exhibited distinctive morphological traits both aboveground and belowground, implying high tolerance to herbivory. Aboveground, herbivory tolerance is manifested in the form of miniaturization and densification of culms, whereas belowground tolerance is manifested in the form of lower biomass and thinner rhizomes with more nodes and shorter internodes. Additionally, herbivory increases the proportion of reserves allocated belowground, even though aboveground overcompensation occurs at the cost of belowground biomass.

\section{Conflict of Interests}

The authors declare that there is no conflict of interests regarding the publication of this paper.

\section{Acknowledgments}

The authors are very grateful to Mr. Samten Nidup, Mr. Dhurba Ghalley, Mr. Phurpa Thinley, and Mr. Sangay for their unfailing assistance in maintaining this experiment for 16 years and collecting the field data.

\section{References}

[1] B. Thornton and P. Millard, "Effects of severity of defoliation on root functioning in grasses," Journal of Range Management, vol. 49, no. 5, pp. 443-447, 1996.

[2] K. McPherson and K. Williams, "The role of carbohydrate reserves in the growth, resilience, and persistence of cabbage palm seedlings (Sabal palmetto)," Oecologia, vol. 117, no. 4, pp. 460-468, 1998.

[3] P. Tiffin, "Mechanisms of tolerance to herbivore damage: what do we know?" Evolutionary Ecology, vol. 14, no. 4"6, pp. 523$536,2000$.

[4] R. Karban and I. T. Baldwin, Induced Responses to Herbivory, The University of Chicago Press, Chicago, Ill, USA, 1997.

[5] S. Y. Strauss and A. A. Agrawal, "The ecology and evolution of plant tolerance to herbivory," Trends in Ecology and Evolution, vol. 14, no. 5, pp. 179-185, 1999.

[6] M. Benot, C. Mony, S. Puijalon et al., "Responses of clonal architecture to experimental defoliation: a comparative study between ten grassland species," Plant Ecology, vol. 201, no. 2, pp. 621-630, 2009.

[7] M. Trlica and L. Rittenhouse, "Grazing and plant performance," Ecological Applications, vol. 3, pp. 21-23, 1993.

[8] Z. Wang, L. Li, X. Han, and M. Dong, "Do rhizome severing and shoot defoliation affect clonal growth of Leymus chinensis at ramet population level?" Acta Oecologica, vol. 26, no. 3, pp. 255-260, 2004.

[9] H.-D. Liu, F.-H. Yu, W.-M. He, Y. Chu, and M. Dong, "Clonal integration improves compensatory growth in heavily grazed ramet populations of two inland-dune grasses," Flora: Morphology, Distribution, Functional Ecology of Plants, vol. 204, no. 4, pp. 298-305, 2009.

[10] A. A. Royo and W. P. Carson, "On the formation of dense understory layers in forests worldwide: consequences and implications for forest dynamics, biodiversity, and succession," Canadian Journal of Forest Research, vol. 36, no. 6, pp. 13451362,2006

[11] L. O. George and F. A. Bazzaz, "The fern understory as an ecological filter: emergence and establishment of canopy-tree seedlings," Ecology, vol. 80, no. 3, pp. 833-845, 1999. 
[12] B. M. Kumar, "Assessment of standing stock of thorny bamboo [Bambusa bambos (L.) Voss] in the homegardens of Palakkad and Malappuram districts in Kerala," Journal of Tropical Agriculture, vol. 46, no. 1-2, pp. 32-37, 2008.

[13] J. D. Derner and D. D. Briske, "Below-ground carbon and nitrogen accumulation in perennial grasses: a comparison of caespitose and rhizomatous growth forms," Plant and Soil, vol. 237, no. 1, pp. 117-127, 2001.

[14] S. E. Smith, "Variation in response to defoliation between populations of Bouteloua curtipendula var. caespitosa (Poaceae) with different livestock grazing histories," The American Journal of Botany, vol. 85, no. 9, pp. 1266-1272, 1998.

[15] J. T. Fahnestock and J. K. Detling, "Morphological and physiological responses of perennial grasses to long-term grazing in the Pryor Mountains, Montana," The American Midland Naturalist, vol. 143, no. 2, pp. 312-320, 2000.

[16] A. F. Sbrissia, S. C. da Silva, C. A. B. de Carvalho et al., "Tiller size/density compensation in grazed coastcross bermudagrass swards," Science and Agriculture, vol. 58, pp. 655-665, 2001.

[17] L. Yan, G. Zhou, and F. Zhang, "Effects of different grazing intensities on grassland production in China: a meta-analysis," PLoS ONE, vol. 8, no. 12, Article ID e81466, 2013.

[18] W. Roder, K. Dorji, and G. Gratzer, "Nutrient flow from the forest-source of life for traditional Bhutanese agriculture," Centralblatt für das gesamte Forstwesen, vol. 120, no. 1, pp. 6572, 2003.

[19] A. H. Taylor, "Culm dynamics and dry matter production of bamboos in the Wolong and Tangjiahe giant panda reserves, Sichuan, China," Journal of Applied Ecology, vol. 24, no. 2, pp. 419-433, 1987.

[20] S. Takatsuki, "Effects of sika deer on vegetation in Japan: a review," Biological Conservation, vol. 142, no. 9, pp. 1922-1929, 2009.

[21] S. Yokoyama and E. Shibata, "The effects of sika-deer browsing on the biomass and morphology of a dwarf bamboo, Sasa nipponica, in Mt. Ohdaigahara, central Japan," Forest Ecology and Management, vol. 103, no. 1, pp. 49-56, 1998.

[22] A. Darabant, P. B. Rai, K. Tenzin, W. Roder, and G. Gratzer, "Cattle grazing facilitates tree regeneration in a conifer forest with palatable bamboo understory," Forest Ecology and Management, vol. 252, no. 1-3, pp. 73-83, 2007.

[23] A. Gansser, The Geology of the Bhutan Himalaya, Birkhäuser, Boston, Mass, USA, 1983.

[24] J. Rosset, Compilation of Available Weather Data in the Bumthang Region 1974 to 1997, Renewable Natural Resources Research Centre Jakar, Bumthang, Bhutan, 1999.

[25] S. Dorji, K. Vernes, and R. Rajaratnam, "Habitat correlates of the red panda in the temperate forests of Bhutan," PLoS ONE, vol. 6, no. 10, Article ID e26483, 2011.

[26] C. Stapleton, Bamboos of Bhutan: an Illustrated Guide, The Royal Botanic Gardens, Kew, UK, 1994.

[27] C. Parker, Weeds of Bhutan, National Plant Protection Center, Department of Agriculture, Ministry of Agriculture, Thimphu, Bhutan, 1992.

[28] H. J. Noltie, Flora of Bhutan, Royal Botanic Garden Edinburgh and Royal Government of Bhutan, The Charlesworth Group, Huddersfield, UK, 2000.

[29] A. Darabant, P. B. Rai, K. Tenzin, T. Sangay, and G. Gratzer, Bamboo Competition and Favorable Microsites Determine Recruitment of Tsuga Dumosa Seedlings at Different Spatial Scales, RNR-RC Jakar, Bumthang, Bhutan, 2007.
[30] W. Roder, K. Wangdi, P. Gyamtsho, and K. Dorji, Feeding the Herds-Improving Fodder Resources in Bhutan, International Centre for Integrated Mountain Development, Kathmandu, Nepal, 2001.

[31] K. Wangchuk, M. Wurzinger, A. Darabant, G. Gratzer, and W. Zollitsch, "The changing face of cattle raising and forest grazing in the Bhutan Himalaya," Mountain Research and Development, vol. 34, pp. 131-138, 2014.

[32] S. Landau and B. S. Everitt, A Handbook of Statistical Analyses Using SPSS, Chapman \& Hall/CRC Press, 2004.

[33] S. C. Malab, C. B. Batin, B. S. Malab, M. A. Alipon, and D. J. Midmore, "Improving productivity of a previously unmanaged Bambusa blumeana plantation for culms and shoots in Ilocos Norte, the Philippines," in Proceedings of the ACIAR, pp. 24-53, Los Baños, Philippines, 1999.

[34] S. T. S. Lepcha, N. S. Bisht, C. J. Singh, and V. Dhiman, "Impact of cultural operations on the production of new culms in Dendrocalamus strictus (Roxb.) in Uttarkhand," Indian Forester, vol. 34, pp. 859-865, 2008.

[35] S. J. McNaughton, "Compensatory plant growth as a response to herbivory," Oikos, vol. 40, no. 3, pp. 329-336, 1983.

[36] M. Oesterheld and S. J. McNaughton, "Intraspecific variation in the response of Themeda triandra to defoliation: the effect of time of recovery and growth rates on compensatory growth," Oecologia, vol. 77, no. 2, pp. 181-186, 1988.

[37] R. Vaylay and E. van Santen, "Grazing induces a patterned selection response in tall fescue," Crop Science, vol. 39, no. 1, pp. 44-51, 1999.

[38] M. Peintinger, The effects of habitat area, management and altitude on species diversity in Montane wetlands [Ph.D. thesis], University of Zürich, Zürich, Switzerland, 1999.

[39] D. C. Franklin, "Wild bamboo stands fail to compensate for a heavy 1-year harvest of culm shoots," Forest Ecology and Management, vol. 237, no. 1-3, pp. 115-118, 2006.

[40] D. C. Franklin, L. D. Prior, N. J. Hogarth, and C. R. McMahon, "Bamboo, fire and flood: consequences of disturbance for the vegetative growth of a clumping, clonal plant," Plant Ecology, vol. 208, no. 2, pp. 319-332, 2010.

[41] J. M. Vázquez-López, H. Vibrans, E. García-Moya, J. I. ValdezHernández, A. Romero-Manzanares, and R. Cuevas-Guzmán, "Effects of harvesting on the structure of a neotropical woody bamboo otatea: guaduinae populations," Interciencia, vol. 29, no. 4, pp. 207-211, 2004.

[42] S. Zhou, J. Huang, Y. Zhang et al., "Effects of wildness training giant pandas'grazing and artificial harvesting on clone population biomass of umbrella bamboo (Fargesia robustd)," Chinese Journal of Applied and Environmental Biology, vol. 18, no. 1, pp. 1-8, 2012.

[43] J. G. Carman and D. D. Briske, "Morphologic and allozymic variation between long-term grazed and non-grazed populations of the bunchgrass Schizachyrium scoparium var. frequens," Oecologia, vol. 66, no. 3, pp. 332-337, 1985.

[44] M. B. Forde, M. J. M. Hay, and J. L. Brock, "Development and growth characteristics of temperate perennial legumes," in Persistence of Forage Legumes, pp. 91-109, ASA, CSSA and SSSA, Honolulu, Hawaii, USA, 1989.

[45] B. W. Kim and K. A. Albrecht, "Defoliation effects on root and rhizome development of Kura clover," Asian-Australasian Journal of Animal Sciences, vol. 19, no. 5, pp. 690-694, 2006.

[46] M. M. Esmaeili, A. Bonis, J. Bouzillé, C. Mony, and M. Benot, "Consequence of ramet defoliation on plant clonal propagation 
and biomass allocation: example of five rhizomatous grassland species," Flora: Morphology, Distribution, Functional Ecology of Plants, vol. 204, no. 1, pp. 25-33, 2009.

[47] G. J. A. Ryle, C. E. Powell, and A. J. Gordon, "Defoliation in white clover: regrowth, photosynthesis and N2 fixation," Annals of Botany, vol. 56, no. 1, pp. 9-18, 1985.

[48] C. A. Harris and M. J. Blumenthal, "Rhizome development of defoliated Grassland Maku," in Proceedings of the 10th Annual Conference on Grassland Society, 1995.

[49] R. J. Lucas, A. J. E. Moorhead, W. W. Nichol, and P. Jarvis, "Frequent grazing by sheep reduced Caucasian clover cover and rhizome biomass in ryegrass pasture," in Proceedings of the New Zealand Grassland Association, 1998.

[50] X. Dong, F.-C. Cheng, D. Wang, G. Wang, B. D. Patton, and P. E. Nyren, "Mixed-grass prairie rhizome biomass is influenced by cattle grazing intensity," Grass and Forage Science, vol. 68, no. 1, pp. 199-204, 2013.

[51] J. L. Nus and C. F. Hodges, "Tiller and rhizome growth of waterstressed Poa pratensis "Merion" infected by Ustilago striiformis or Ustilago agropyri," Plant Diseases, vol. 74, pp. 886-888, 1990.

[52] D. G. Stout and B. Brooke, "Rhizomes and roots below clipped pinegrass tillers have a higher percent carbohydrates when attached to other nonclipped tillers," Journal of Range Management, vol. 30, pp. 276-277, 1985.

[53] R. Li, M. J. A. Werger, H. J. During, and Z. C. Zhong, "Carbon and nutrient dynamics in relation to growth rhythm in the giant bamboo Phyllostachys pubescens," Plant and Soil, vol. 201, no. 1, pp. 113-123, 1998.

[54] Y. Li, T. Luo, and Q. Lu, "Plant height as a simple predictor of the root to shoot ratio: evidence from alpine grasslands on the Tibetan Plateau," Journal of Vegetation Science, vol. 19, no. 2, pp. 245-252, 2008.

[55] C. Körner, Alpine Plant Life: Functional Plant Ecol of High Mountain Ecosysytems, Springer, Berlin, Germany, 1999. 

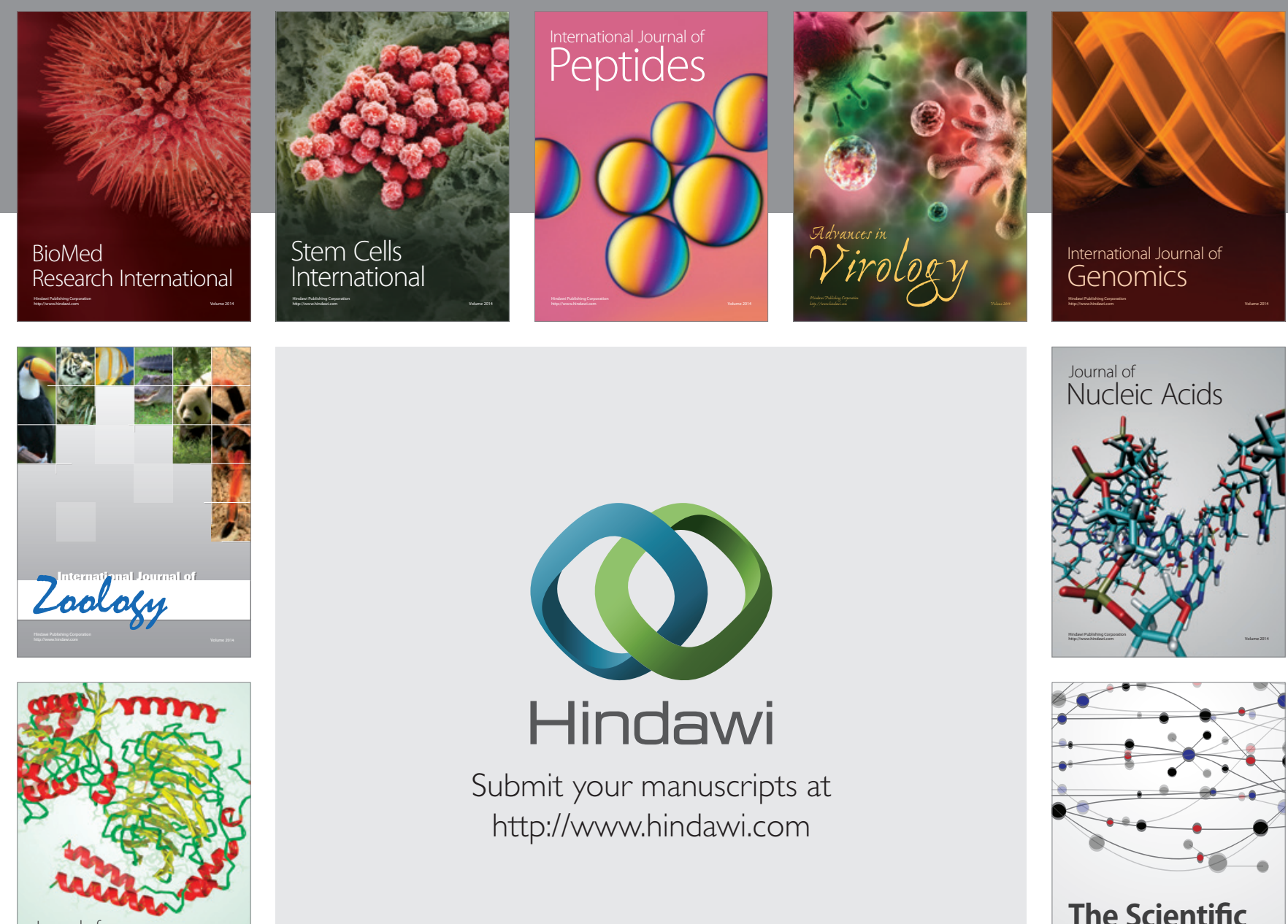

Submit your manuscripts at

http://www.hindawi.com

Journal of
Signal Transduction
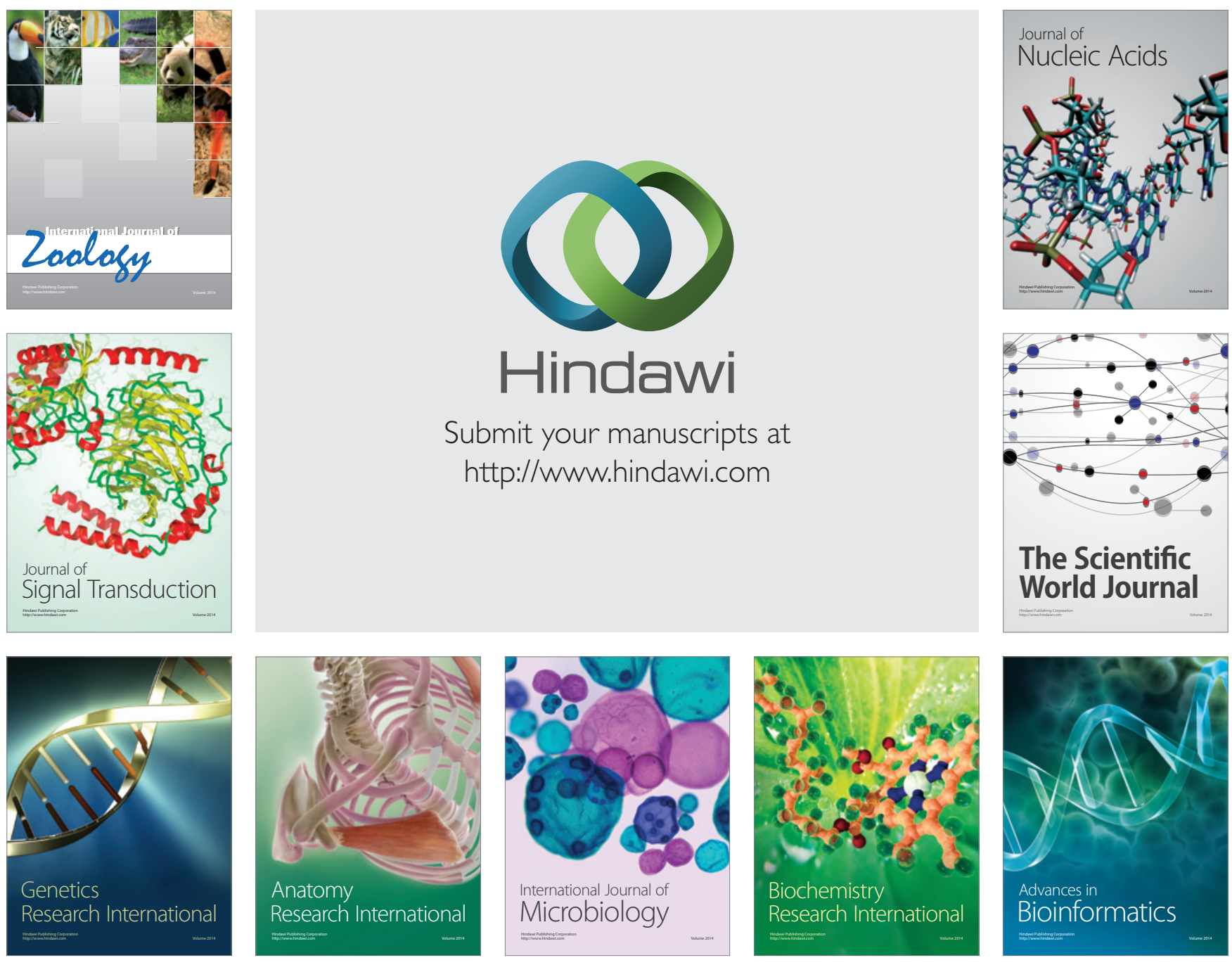

The Scientific World Journal
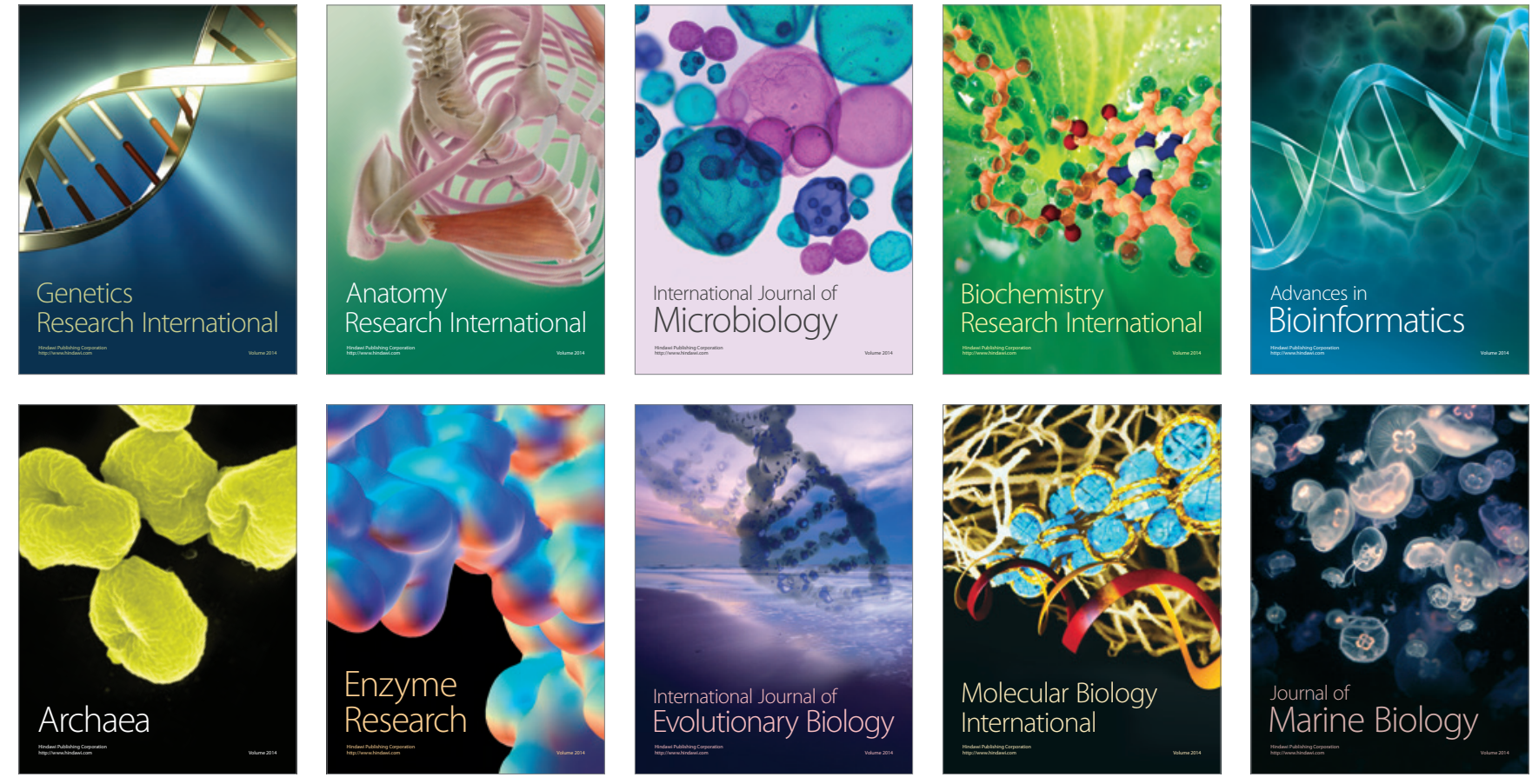